\title{
THE WILD SUNFLOWERS COLLECTION IN NOVI SAD
}

Atlagić, J. ${ }^{*}$, Terzić, S., Škorić, D., Marinković, R., Vasiljević, Lj., Panković-Saftić, D.

Institute of Field and Vegetable Crops, Oil Crops departament, 21000 Novi Sad, Maksima Gorkog 30, Serbia

Received: September 10, 2005 Accepted: March 25, 2006

SUMMARY

Lowered genetic variability in the cultivated sunflower and use of interspecies hybridization in sunflower breeding were the main reasons to establish the wild species collection. Wild species were collected during collecting trips performed jointly by researchers from Novi Sad and Fargo from 1980 to 1991. A total of 917 accessions were gathered. Different numbers of species (1-37) and populations (52-384) were gathered in each trip and wild sunflower habitats were inspected in 6-21 US federal states. Presently, there are 21 perennial and 7 annual species in the collection, represented by 447 accessions. The perennial species are grown in quarantine fields ( 311 accessions) and kept in temporary seed storage at $+4^{\circ}$ (163 accessions). Annual species are sawn each year and 136 accessions are kept in temporary seed storage. Seed reserves vary from a few seeds to several thousand per accession and all of them were produced in the period between 1998 and 2004. Several problems were encountered in the course of the establishment, maintenance and utilization of the collection: 1. Occasional errors in species determination during collection trips were caused by the presence of natural hybrids, heterogeneity of natural populations and differences in ploidy within the same species; 2 . The local continental climate caused loss in material due to winterkill and inability of some species to complete the vegetative cycle; 3 . Perennial species were difficult to grow because of low seed viability; 4 . Low self-fertility or complete selfsterility precluded seed production and renewal of seed reserves; 5 . Wild species were difficult to utilize as a source of desirable genes because of their cross incompatibility with cultivated sunflower.

The collection of wild sunflower species has mostly been used for development of disease resistant or tolerant genotypes, new $\mathrm{cms}$ and $R f$ genes and for breeding of special-purpose hybrids.

Key words: sunflower, wild species, collection, maintenance, utilization

* Corresponding author, Phone: +381 214898 401, Fax: +381 21413 833, e-mail: atlagic@ifvcns.ns.ac.yu 


\section{INTRODUCTION}

The main reason for establishing a collection of wild sunflower species is the reduced genetic variability of the domesticated sunflower for a number of agronomic characteristics, especially resistance to diseases. In recent years, interspecific hybridization has been extensively applied in sunflower breeding, i.e., wild sunflower species have been used as sources of desirable genes for a number of characteristics (Seiler, 1992; Seiler and Reiseberg, 1997).

The systematics and taxonomy of the genus Helianthus have been repeatedly amended and revised. The number of species thought to belong to the genus has varied from several hundred to several scores. The systematics of Schilling and Heiser (1981) has been used most frequently in the recent period and it is used in this paper. According to Schilling and Heiser, the genus Helianthus comprises 49 species, 11 annuals and 38 perennials, divided on the basis of mutual similarity in four section and four series. The most recent data of Seiler (2005) indicate that Helianthus comprises 51 species, 14 annuals and 37 perennials that grow in their natural habitats in North America.

Taking in consideration the importance of wild sunflower species, the objective of this paper was to review the 25-year results on the collection, maintenance and utilization of the wild sunflower species from the Novi Sad collection.

\section{MATERIAL AND METHODS}

A major part of the collection of wild sunflower species was collected in the course of collecting trips organized in different federal states of the USA in the period 1980-1991. Researchers from Novi Sad and Fargo took part in these trips. Additional seed samples were obtained from two more collecting trips, to Canada and Montenegro, and from other collection centers and gene banks.

The Novi Sad collection was maintained in the field and in cold chambers at $+4^{\circ} \mathrm{C}$. Perennial species were permanently grown in the field, annual ones were planted each growing season. From 1981 to 1987 , the perennials were grown in $70 \times 40 \mathrm{~cm}$ cylinders made of thick PVC foil. The cylinders were embedded in the soil and filled with a mixture of sand, peat and chernozem soil. Each spring, new shoots from rhizomes or tubers were selected and placed in the cylinders, three shoots per cylinder, five cylinders per population. As individual plants were favored in that way, they began to differ phenotypically from plants of the same species growing in natural habitat. Therefore, starting from 1987, the perennials were grown in $80 \times 120 \times 80 \mathrm{~cm}$ beds which were bordered with PVC foil to prevent expansion and mixing of populations. To simulate the natural conditions of growing, the aboveground plant parts were cut each fall and new shoots allowed to grow each spring. The annual species were planted each spring. The planting was done either directly or from seeds germinated in the laboratory, with seedlings grown in the greenhouse and transplanted in the field at the stage of 3-4 pairs of leaves.

Surplus seeds and the newly produced seeds of the wild species were kept in cold chamber $\left(+4^{\circ} \mathrm{C}\right)$. 
Seeds of the wild species were produced by self-pollination. Two methods were employed, isolation bags and cages. Seed viability was determined under laboratory conditions (at $23-25^{\circ} \mathrm{C}$ on wet filter paper in Petri dishes). The scarification method of Chandler and Jan (1985) has been tried.

Genetic divergence was tested on the basis of morphological and molecular variability (clustering according to IBPGR descriptors and SSR markers). Crossability was tested on the basis of direct and reciprocal crossing of wild species from the collection with lines of cultivated sunflower employing conventional hybridization methods.

\section{RESULTS AND DISCUSSION}

During the 7 collecting trips conducted from 1980 to 1991,917 accessions were collected. The trips varied in the number of collected species (1-37) and populations (52-384) (Table 1).

Table 1: Collecting trips 1980-1991

\begin{tabular}{|c|c|c|c|c|}
\hline Collected by & Year & $\begin{array}{l}\text { Number of } \\
\text { states visited }\end{array}$ & $\begin{array}{l}\text { Number of } \\
\text { species }\end{array}$ & $\begin{array}{l}\text { Number of } \\
\text { populations }\end{array}$ \\
\hline $\begin{array}{l}\text { Seiler, G. (USDA-ARS), } \\
\text { Ćuk, L. (YUGIFVC) }\end{array}$ & 1980. & 21 (USA) & 37 & 384 \\
\hline $\begin{array}{l}\text { Marinković, R. (YUGIFVC), } \\
\text { Miller, J. (USDA-ARS) }\end{array}$ & 1984 & 1 (Canada) & 7 & 88 \\
\hline $\begin{array}{l}\text { Škorić, D. (YUGIFVC), Seiler, G. (USDA-ARS), } \\
\text { Rooth, (USDA-ARS), }\end{array}$ & 1985 & 12 (USA) & 13 & 88 \\
\hline $\begin{array}{l}\text { Seiler, G. (USDA-ARS), Pomeroy, J. (USDA-ARS), } \\
\text { Marinković, R. (YUGIFVC) }\end{array}$ & 1987 & 6 (USA) & 7 & 52 \\
\hline $\begin{array}{l}\text { Dozet, B. (YUGIFVC), Seiler, G. (USDA-ARS), } \\
\text { Pomeroy, (USDA-ARS), Gavrilova, V. (SUNWIR) }\end{array}$ & 1989 & 6 (USA) & 12 & 84 \\
\hline $\begin{array}{l}\text { Dozet, B. (YUGIFVC), } \\
\text { Marinković, R. (YUGIFVC) }\end{array}$ & 1990 & $\begin{array}{c}1 \text { (Montene- } \\
\text { gro) }\end{array}$ & 1 & 81 \\
\hline $\begin{array}{l}\text { Marinković, R. (YUGIFVC), Seiler, G. (USDA-ARS), } \\
\text { Stauffer, C. (USDA-ARS), Duhoon, S. (NBPGR) }\end{array}$ & 1991 & 7 (USA) & 9 & 140 \\
\hline
\end{tabular}

Of the 49 sunflower species in the genus Helianthus, the collection included 43 species - section Helianthus was complete, and 6 species were missing from the group of perennials. Regrettably, 14 species have been lost in the previous period, 4 annuals and 10 perennials. The reasons for this were in the first place different conditions for growing in the collection and in the original natural habitat (winterkill, long growing season), as well as low self-fertility and poor viability of seed of the wild species. At present, the collection comprises 21 perennial and 7 annual species. A total number of accessions in the collection is 447 . Reserve seeds of the populations of annual species range from several scores to several thousands (Table 2). The situation is similar with the perennial species, where the discrepancy in the number of populations registered in the gene bank and the number of available reserve seed lots indicates that a certain number of populations have been lost. From the initial 41 populations of $H$. tuberosus, only 16 remained. In the case of 
H. grosserratus, 9 populations remained from the original 29. On the other hand, the number of perennial populations maintained in the field exceeds for most part the number of populations registered in the gene bank as well as the number of populations having seeds in storage (Table 3 ). It should be mentioned that the number of reserve seeds of the perennials varies from one seed to several hundreds, exceptionally several thousands. Compared with the reserve seeds of the annuals, the number of reserve seeds of the perennials is considerably smaller.

Table 2: The collection of annual wild species

\begin{tabular}{|c|c|c|c|}
\hline \multirow{2}{*}{ Species } & \multicolumn{2}{|c|}{ No. of populations } & \multirow{2}{*}{ No. of seeds } \\
\hline & In gene bank date base & With seed reserves & \\
\hline H. annuus & 108 & 70 & $10-2539$ \\
\hline H. petiolaris & 33 & 25 & $80-9130$ \\
\hline H. neglectus & 4 & 4 & $1564-4838$ \\
\hline H. debilis & 21 & 13 & $33-5490$ \\
\hline H. praecox & 15 & 14 & $335-10710$ \\
\hline H. argophyllus & 7 & 7 & $1616-10396$ \\
\hline H. niveus & 4 & 3 & $259-5910$ \\
\hline
\end{tabular}

Table 3: The collection of perennial wild species

\begin{tabular}{lcccc}
\hline Species & \multicolumn{2}{c}{ Number of populations } & Number & Number of \\
\cline { 2 - 3 } & $\begin{array}{c}\text { In gene bank } \\
\text { data base }\end{array}$ & $\begin{array}{c}\text { With seed } \\
\text { reserves }\end{array}$ & $\begin{array}{c}\text { Noeds } \\
\text { populations } \\
\text { in the field }\end{array}$ \\
\hline H. tuberosus & 41 & 16 & $1-650$ & 112 \\
H. rigidus (H. pauciflorus) & 13 & 12 & $1-400$ & 11 \\
H. mollis & 7 & 5 & $3-1162$ & 6 \\
H. maximiliani & 36 & 32 & $1-8630$ & 60 \\
H. divaricatus & 10 & 10 & $8-680$ & 8 \\
H. decapetalus & 8 & 7 & $17-622$ & 7 \\
H. grosseserratus & 29 & 9 & $2-335$ & 31 \\
H. nuttallii & 23 & 22 & $1-399$ & 15 \\
H. strumosus & 20 & 12 & $2-354$ & 20 \\
H. laevigatus & 7 & 7 & $7-91$ & 8 \\
H. glaucophyllus & 1 & 1 & 38 & 1 \\
H. giganteus & 16 & 15 & $1-1800$ & 19 \\
H. eggertii & 2 & 2 & $1-9$ & 1 \\
H. hirsutus & 4 & 3 & $3-280$ & 2 \\
H. californicus & 1 & 1 & 1 & 1 \\
H. resinosus & 2 & 2 & 125,4858 & 2 \\
H. silphioides & 1 & 1 & 13 & 1 \\
H. atrorubens & 1 & 1 & 2 & 1 \\
H. microcephalus & 2 & 2 & 28,300 & 2 \\
H. smithii & 2 & 2 & 13,90 & 2 \\
H. glaucophyllus & 1 & 1 & 10 & 1 \\
\hline & & & &
\end{tabular}


Seed production has been a serious problem in maintaining the collection. The problem was due to low self-fertility, especially in the case of the perennial species. Data for the period 2001-2004 show that seed production was more successful with annual than with perennial populations (Figure 1).

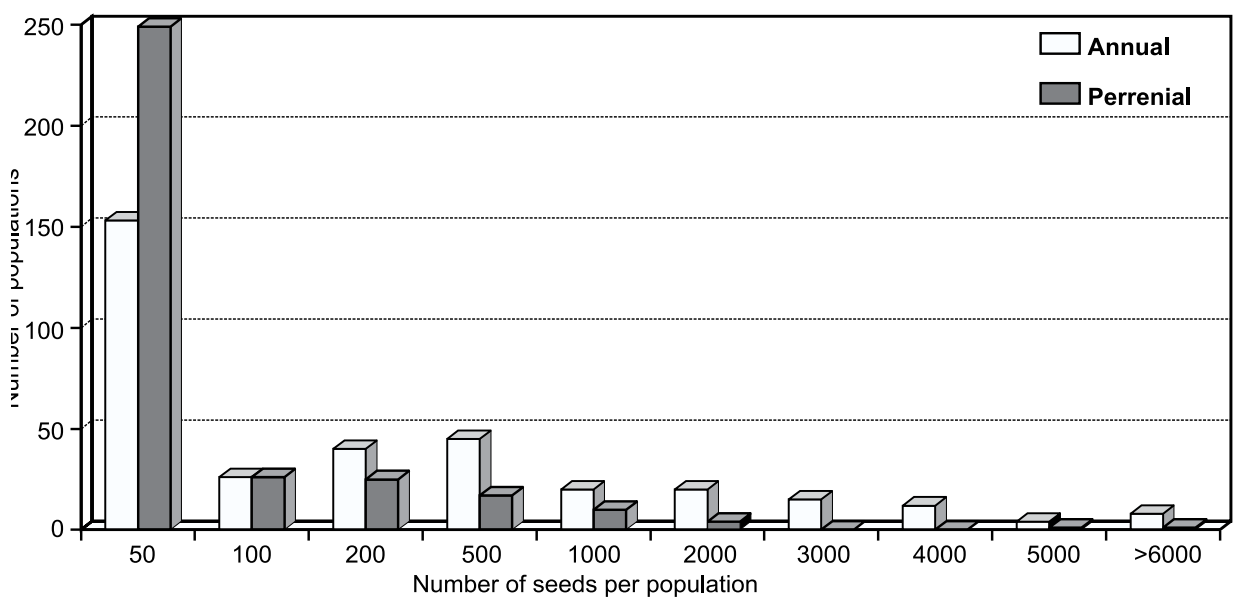

Figure 1: Wild sunflower seed production in the period from 2001 to 2004

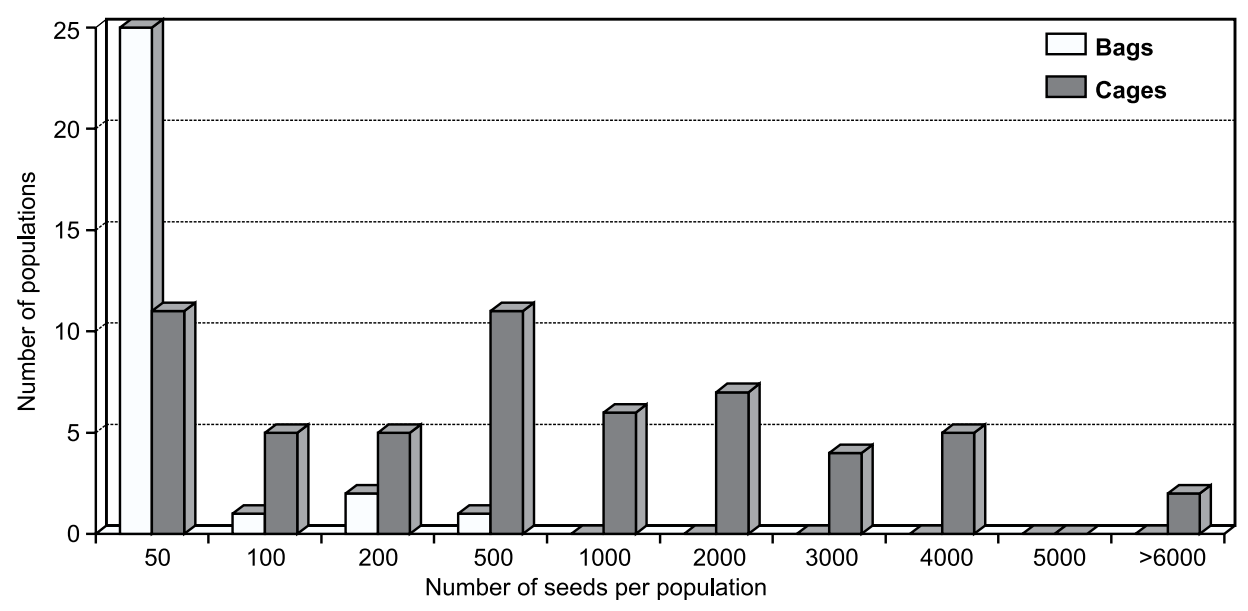

Figure 2: Seed production of annual species as related with the type of isolation

Method of seed production affects considerably the amount of seed obtained. At the beginning, inflorescences had been isolated with paper bags. As that method rendered exceedingly small amounts of seed, we switched to the method provisionally called "pollen mixture method" (PMM) in which pollen was manually transferred from inflorescence to inflorescence within a population. That method worked well with certain species. However, some perennial species remained almost completely self-sterile. A solution to the problem was sought in the use of cages with 
beehives, which simulated the natural conditions for pollination. The results obtained in the period 2001-2004 showed that cages were used effectively, especially in the production of seed of annual species (except the production of small amounts of seed, around 50) (Figure 2). Cages were not effective with perennial species, especially for production of large amounts of seed (>500) (Figure 3).

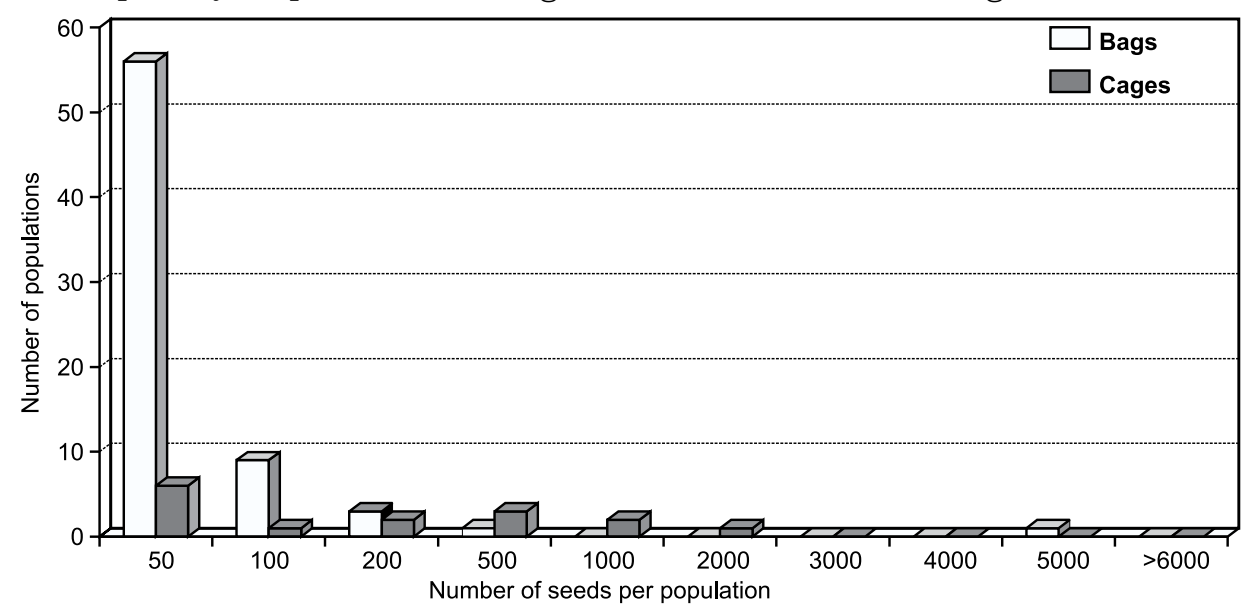

Figure 3: Seed production of perennial species as related with the type of isolation

Poor seed viability posed a great problem in the maintenance of the collection. Long-term data show that the viability in the annual species ranged from 0 to $100 \%$ (differences among populations of a single species). The average values for seed viability in the 14 tested annual species ranged from $8.1 \%$ (H. exillis) to $52.5 \%$ (H. praecox) (Table 4).

Table 4: Seed germination of annual wild species

\begin{tabular}{lccccc}
\hline Species & $\begin{array}{c}\text { Number of } \\
\text { populations }\end{array}$ & $\begin{array}{c}\text { Germination } \\
\%\end{array}$ & $\mathrm{X}$ & $\mathrm{S}$ & $\mathrm{V}$ \\
\hline H. annuus & 49 & $0-100$ & 43.4 & 25.2 & 58.0 \\
H. agrestis & 2 & $27.5-50$ & 38.7 & 15.9 & 41.0 \\
H. argophyllus & 4 & $10-90$ & 47.5 & 33.0 & 69.0 \\
H. anomalus & 6 & $5-36.7$ & 24.1 & 13.7 & 571 \\
H. exilis & 2 & $0-16.2$ & 8.1 & 11.4 & 141.0 \\
H. debilis & 7 & $28.7-57.5$ & 43.6 & 106 & 24.4 \\
H. niveus & 2 & $6.2-30$ & 22.1 & 9.7 & 44.0 \\
H. petiolaris & 10 & $5-23.7$ & 13.6 & 8.7 & 630 \\
H. praecox & 6 & $26.2-73.3$ & 52.5 & 21.4 & 40.1 \\
H. paradoxus & 3 & $0-35$ & 14.6 & 18.2 & 124.8 \\
H. floridanus & 2 & $25.5-31.2$ & 28.3 & 4.0 & 14.2 \\
H. heterophyllus & 5 & $0-13.3$ & 66 & 5.3 & 79.8 \\
H. radula & 4 & $13.7-63.3$ & 42.9 & 23.7 & 55.3 \\
H. deserticola & 3 & $13.3-20$ & 16.6 & 3.3 & 20.0 \\
\hline
\end{tabular}


In the 21 perennial species, each represented by 1-3 populations, seed viability ranged from 0 (H. strumosus, $H$. angustifollius, $H$. simulans) to $93.3 \%$ (H. mollis) (Table 5).

Table 5: Seed germination of perennial wild species

\begin{tabular}{lccc}
\hline Species & No. of populations & Germination \% & X \\
\hline H.gracilentus & 1 & 53.3 & - \\
H. pumilus & 1 & 56.7 & - \\
H. mollis & 1 & 93.3 & - \\
H. occidentalis & 1 & 60.0 & - \\
H. hirsutus & 1 & 13.3 & - \\
H. eggertii & 1 & 15 & - \\
H. strumosus & 1 & 0 & - \\
H. tuberosus & 1 & 20 & 7.8 \\
H. rigidus & 3 & $0-20$ & - \\
H. giganteus & 1 & 10 & - \\
H. grosseserratus & 1 & 60 & 40 \\
H. nuttallii & 2 & $10-70$ & 5 \\
H. maximiliani & 3 & $0-15$ & - \\
H. resinosus & 1 & 50 & - \\
H. salicifolius & 1 & 13.3 & - \\
H. microcephalus & 1 & 33.3 & - \\
H. smithii & 1 & 20 & - \\
H. angustifolius & 1 & 0 & - \\
H. silphioides & 1 & 40 & - \\
H. simulans & 1 & 0 & - \\
H. atrorubens & 1 & 50 & -
\end{tabular}

Table 6: Effect of seed scarification on germination

\begin{tabular}{lcccccc}
\hline $\begin{array}{l}\text { Annual wild } \\
\text { species }\end{array}$ & $\begin{array}{c}\text { Number of } \\
\text { populations }\end{array}$ & $\begin{array}{c}\text { Germination of } \\
\text { non-scarified seeds (\%) }\end{array}$ & X1 & $\begin{array}{c}\text { Germination of } \\
\text { scarified seeds (\%) }\end{array}$ & X2 & X2-X1 \\
\hline H. annuus & 29 & $0-24$ & 3.9 & $0-36$ & 17.3 & 13.4 \\
H. argophyllus & 4 & $2-13.3$ & 8.8 & $133-33.3$ & 21.1 & 12.3 \\
H. anomalus & 6 & 0 & 0 & $0-16.6$ & 9.4 & 9.4 \\
H. agrestis & 1 & 28 & 28 & 36 & 36 & 8 \\
H. praecox & 5 & $14-22$ & 18.4 & $20-32$ & 26 & 7.6 \\
H. paradoxus & 2 & 0 & 0 & $0-12$ & 15 & 15 \\
H. deserticola & 3 & $3-33.3$ & 18.7 & $166-86.6$ & 49.9 & 31.2 \\
H. debilis & 3 & $2-43$ & 16.3 & $11-55$ & 37.5 & 21.2 \\
H. exilis & 2 & $0-2$ & 1 & $14-15$ & 14.5 & 13.5 \\
H. neglectus & 3 & $0-6$ & 2.7 & $6-20$ & 15.3 & 12.6 \\
H. niveus & 3 & 0 & 0 & $12-15$ & 13.3 & 13.3 \\
H. petiolaris & 17 & $0-35$ & 2.6 & $2-40$ & 11.6 & 9 \\
\hline X(X2X1) & & & & &
\end{tabular}

$\mathrm{X}(\mathrm{X} 2-\mathrm{X} 1)=13.9 \%$ 
Various methods for viability enhancement mentioned in literature have been tried. Notable improvements in seed viability have been obtained with the scarification method which involved removal of hull and testa. When applied to 11 annual species (73 populations), this method increased their viability from 8 to $31.2 \%$ or $13.9 \%$ on the average (Table 6 ). In the case of 9 perennial species ( 15 populations), viability was increased from 6 to $34 \%$ or $17.2 \%$ on the average (Table 7 ).

Table 7: Effect of seed scarification on germination

\begin{tabular}{|c|c|c|c|c|c|c|}
\hline $\begin{array}{l}\text { Perennial wild } \\
\text { species }\end{array}$ & $\begin{array}{l}\text { Number of } \\
\text { populations }\end{array}$ & $\begin{array}{c}\text { Germination of } \\
\text { non-scarified seeds (\%) }\end{array}$ & $\mathrm{X} 1$ & $\begin{array}{c}\text { Germination of } \\
\text { scarified seeds (\%) }\end{array}$ & $\mathrm{X} 2$ & $X 2-X 1$ \\
\hline H. mollis & 3 & $22-34$ & 26,7 & $32-42$ & 36 & 9,3 \\
\hline H. hirsutus & 2 & 0 & 0 & $8-10$ & 9 & 9 \\
\hline H. strumosus & 1 & 18 & 18 & 30 & 30 & 12 \\
\hline H. tuberosus & 1 & 0 & 0 & 30 & 30 & 30 \\
\hline H. rigidus & 2 & 0 & 0 & $6-10$ & 8 & 8 \\
\hline H. maximiliani & 2 & $0-8$ & 4 & $28-30$ & 29,5 & 25,5 \\
\hline H. laevigatus & 1 & 6 & 6 & 12 & 12 & 6 \\
\hline H. atrorubens & 2 & $2-20$ & 11 & $20-44$ & 32 & 21 \\
\hline H. grosseserratus & 1 & 4 & 4 & 38 & 38 & 34 \\
\hline
\end{tabular}

$\mathrm{X}(\mathrm{X} 2-\mathrm{X} 1)=17.2 \%$

The species in the collection have been measured and observed according to IBPGR descriptors. The obtained results indicated that extremely high variability for a number of characteristics (Atlagić et al., 1999; Dozet et al., 1993) existed not only among the species but also among population within a single species (Miljanović et al., 2000). The importance of this high variability was demonstrated when crossing populations of the same species with cultivated sunflower. Morphological and molecular variabilities were observed in the two taxonomically close species, H. maximiliani and H. giganteus (Panković et al., 2005), which were frequently used in breeding programs. Despite the problems in maintaining the collection, the fact that all annual and 14 perennial species have been crossed with cultivated sunflower by the conventional hybridization method (Atlagić, 2004) should be considered as success. Several thousand crossings were made, resulting in successful transfer of desirable characteristics into sunflower hybrids from Novi Sad breeding program.

\section{REFERENCES}

Atlagić, J., 2004. Roles of interspecific hybridization and cytogenetic studies in sunflower breeding. Helia 27(41): 1-24.

Atlagić, J., Škorić, D., 1999. Cytogenetic study of Helianthus laevigatus and its $\mathrm{F}_{1}$ and $\mathrm{BC}_{1}$ hybrids with cultivated sunflower, Helianthus annuus. Plant Breeding 118: 555-559.

Chandler, J.M., Jan, C.C., 1985. Comparison of germination techniques for wild Helianthus seeds. Crop Science 25: 356-358.

Dozet, B., Bedov, M., Atlagić J., Marinković, R., 1993. Wild sunflower species-sources of resistance to the sunflower moth (Homeosoma nebulella Hubner; Homeosoma electellum Hulst.). Helia 16(19): 55-60. 
Miljanović, T., Boža, P, Atlagić, J., Škorić, D., 2000. Morphological variability of $H$. giganteus L. and H. maximiliani Sch. populations. Helia 23(32): 45-52.

Panković, D., Atlagić, J., Miljanović, T., Radovanović, N., 2005. Morphological and molecular variability of Helianthus giganteus L. and Helianthus maximiliani Sch. species. Genetika 37(2): 121-130.

Schilling, E.E., Heiser, Ch.B., 1981. Infrageneric classification of Helianthus (Compositae). Taxon 30: 393-403.

Seiler, G.J., 1992. Utilization of wild sunflower species for the improvement of cultivated sunflower. Field Crops Res. 30: 195-230.

Seiler, G.J., Reiseberg, H.L., 1997. Systematics, Origin, and Germplasm Resources of the Wild and Domesticated Sunflower. In: Ed.: Albert A. Schneiter, Sunflower Technology and Production, 21-65, ASA, CSSA, SSSA, Medison, Wisconsin, USA.

Seiler, G.J., Gulya, T.J., 2005. Collection of Rare, Endangered, Threatened, and Intersting Wild Helianthus Species for the USDA-ARS Sunflower Genebank. $10^{\text {th }}$ FAO Consultation Meeting, Novi Sad, July 17-20, pp. 1.

\section{COLECCIÓN DE LAS ESPECIES SILVESTRES DE GIRASOL EN NOVI SAD}

\section{RESUMEN}

La disminuida variabilidad genética en la forma cultivada de girasol y la aplicación de la hibridización interspecie en la mejora genética, han condicionado la formación de una colección de especies silvestres de girasol. La colección de las especies silvestres se ha generado por recolección de semillas en 7 expediciones realizadas por parte de los investigadores de nuestro país y americanos, en diferentes estados de los EE.UU., durante el período comprendido entre 1980 y 1991. Mediante las expediciones realizadas, fue recolectado 917 números de colección en total, donde en cada expedición fue recolectado diferente número de especies (1-37), diferente número de poblaciones (52-384), y donde se inspeccionaron los hábitats en 6-21 estados americanos. Hoy en día, la colección contiene 21 especies perennes y 7 especies anuales, 447 números de colección en total. Las especies perennes se guardan en el campo (311 números de colección) y en las condiciones temporarias de preservación en $+4^{\circ} \mathrm{C}$ (163 números de colección). Las especies anuales se siembran cada año en el campo, y en las condiciones temporales, se preserva 136 números de colección. Las reservas de semilla varían entre varias semillas hasta más de un mil, y fueron producidas en el período comprendido entre 1998 y 2004 . Los resultados del trabajo de varios años en el establecimiento, mantenimiento y aprovechamiento de la colección de especies silvestres, indican varios problemas principales: 1 veces fueron incorrectamente determinadas las especies, lo que condiciona la presencia de los híbridos naturales, la heterogeneidad de las poblaciones y una diferente ploidía dentro de la especie; 2en las cuales se cultivan las especies en la colección, condicionan la pérdida de algunas especies de la colección (congelación, largo período vegetativo etc.); 3imposibilita la obtención de las plantas; 4dad total imposibilita la producción y renovación de las reservas de semilla; 5- la incompatibilidad cross entre las especies silvestres y el girasol cultivado, imposibilita el aprovechamiento de las especies silvestres como la fuente de genes favorables en la mejora genética del girasol cultivado.

La colección de las especies silvestres es más aprovechada en el sentido de generación de genotipos resistentes o tolerantes en los causantes de las enfermedades, generación de nuevos fuentes de genes $\mathrm{cms}$ y del gen $R f$, de nuevos ideotipos y la mejora genética de girasol para los destinos especiales. 


\section{LA COLLECTION DE TOURNESOLS SAUVAGES DE NOVI SAD}

\section{RÉSUMÉ}

Les principales raisons pour établir une collection d'espèces sauvages étaient une variabilité génétique réduite chez le tournesol cultivé et l'utilisation d'hybridation interspécifique dans la sélection du tournesol. Les espèces sauvages ont été rassemblées au cours de voyages de collecte effectués par des chercheurs de Novi Sad et de Fargo de 1980 à 1991. Au total, 917 numéros d'accession ont été rassemblés. Différents nombres d'espèces (1-37) et de populations (52-384) ont été rassemblés à chaque sortie et les habitats des tournesols sauvages ont été examinés dans 6-21 États américains. La collection comprend actuellement 21 espèces vivaces et 7 espèces annuelles, en tout 447 numéros d'accession. Les espèces vivaces sont cultivées dans les champs de quarantaine (311 numéros d'accession) et gardées en entreposage temporaire à $+4^{\circ} \mathrm{C}$ ( 163 numéros d'accession). Les espèces annuelles sont semées chaque année et 136 numéros d'accession sont gardés en entreposage temporaire. Les réserves de semences varient entre quelques semences à plus de mille par numéro d'accession et elles ont toutes été produites entre 1998 et 2004 . Les résultats d'un travail de plusieurs années sur la formation, la conservation et l'utilisation de la collection ont indiqué la présence de quelques problèmes de base : 1. Quelques erreurs occasionnelles au cours de la cueillette ont été causées par la présence d'hybrides naturels, l'hétérogénéité des populations naturelles et des différences de ploïdy dans la même espèce; 2 . Le climat continental local a causé des pertes de matériel à cause du gel et de l'inaptitude de certaines espèces à compléter le cycle végétatif; 3 . Les espèces vivaces se sont développées difficilement à cause d'une viabilité réduite des semences; 4 . une autofertilité réduite ou une autostérilité complète ont empêché la production et la reproduction des réserves de semences; 5 . les espèces sauvages ont été difficiles à utiliser comme source de gènes souhaitables à cause de leur incompatibilité de croisement avec le tournesol de culture.

La collection d'espèces de tournesol sauvage a surtout été utilisée pour le développement de génotypes résistants ou tolérants aux maladies, la création de nouvelles sources de $c m s$ et de gènes $R f$ et pour la culture d'hybrides à buts spécifiques. 